\title{
44. HEAT-FLOW STUDIES IN THE PERU TRENCH SUBDUCTION ZONE ${ }^{1}$
}

\author{
Makoto Yamano ${ }^{2}$ and Seiya Uyeda ${ }^{2}$
}

\begin{abstract}
New heat-flow values were obtained in the central Peru Trench area during site surveys and drilling of Ocean Drilling Program (ODP) Leg 112 by measuring temperatures with ordinary surface heat-flow probes and in the drill holes and by estimating from bottom-simulating reflectors resulting from gas hydrates. The values determined by these methods are consistent with each other within the limits of error. When combined with existing data, heat-flow distribution from the trench to the coast was delineated. Heat flow is lower than $40 \mathrm{~mW} / \mathrm{m}^{2}$ at the bottom of the trench and 40 to $50 \mathrm{~mW} / \mathrm{m}^{2}$ on the landward slope. The low heat flow at the trench bottom can be explained partly by a high sedimentation rate. Heat flow is variable about where the Mendaña Fracture Zone meets the trench. This low heat flow might result from hydrothermal circulation in the fracture zone, which some scientists believe is a new propagating rift. On the landward slope, no significant difference in heat flow is recognized between the northern side and the southern side of the fracture zone, in spite of differences in the age of the subducting plate and the tectonic history. Heat flow on the landward slope may be slightly higher than that in most other subduction zones.
\end{abstract}

\section{INTRODUCTION}

First heat-flow measurements in the Peru Trench area were reported by Von Herzen (1959) as one of the earliest results of marine heat-flow surveys. Several values were then obtained by Von Herzen and Uyeda (1963) during the Risepac expedition. Six of the seven values reported on the landward trench slope or at the bottom of the trench are lower than $50 \mathrm{~mW} / \mathrm{m}^{2}$.

Subsequent heat-fiow studies in other subduction zones revealed that such low heat flow seaward of the arc is a common feature, as well as the high and variable heat flow on the volcanic arc and age-dependent heat flow in the back-arc basins (e.g., Watanabe et al., 1977). Various thermal models for subduction were presented to explain the above pattern of heat-flow distribution (e.g., Hasebe et al., 1970; Toksöz et al., 1971). In the last decade, more detailed heat-flow profiles from the trench to the volcanic arc have been obtained in some areas, such as northern Oregon (Blackwell et al., 1982), southern Mexico (Ziagos et al., 1985), and northeast Japan (Yamano et al., 1987). At the present stage, differences in thermal structures between various subduction zones should be discussed based on the differences in surface heat-flow distribution and various subduction parameters.

From this point of view, it is interesting to study the thermal structure of the Peru subduction zone, especially because a $1500-\mathrm{km}$-long volcanic gap exists in central Peru. However, no heat-flow data were reported off the coast of Peru after the Risepac expedition, while a considerable amount of geophysical and geological data were collected in the Peru-Chile Trench area under the Nazca Plate Project (Woollard and Kulm, 1981). On land, about 30 heat-flow values were obtained from the Peruvian coast to the Andes in Peru and Bolivia (Uyeda et al., 1980; Watanabe et al., 1980; Henry and Pollack, 1988) and more than 50 values were determined in the sedimentary platform and basins to the east of the Andes (Ocola, 1985; Henry and Pollack, 1988). However, most of these values are concentrated in areas near the

\footnotetext{
${ }^{1}$ Suess, E., von Huene, R., et al., 1990. Proc. ODP, Sci. Results, 112 College Station, TX (Ocean Drilling Program).

2 Earthquake Research Institute, University of Tokyo, 1-1-1, Yayoi, Bunkyo-ku, Tokyo 113, Japan.
}

northern and southern ends of Peru, and it was difficult to construct a profile of the heat flow from the trench to the Andes in central Peru.

In the offshore area, this situation has been much improved recently. As a part of the site surveys for Leg 112 in the Peru margin, we conducted heat-flow measurements during the MW8506 cruise of the Moana Wave (Hawaii Institute of Geophysics) in April 1985. New heat-flow data were also obtained during the SEAPERC cruise of the Jean Charcot in 1986 (Pautot et al., 1986). During Leg 112, temperatures were measured in drill holes at most sites.

In addition, heat flow was estimated from the depths of bottom-simulating reflectors (BSRs) resulting from gas hydrate layers found in many seismic-reflection profiles. Combining all these data, we construct here a profile of the heat flow from the trench to the coast in the Peru continental margin.

\section{NEW HEAT-FLOW DATA}

\section{Ordinary Marine Heat-Flow Measurements}

Heat flows were measured during the MW8506 cruise off central Peru using an ordinary marine heat-flow probe. We attempted 43 penetrations; 20 of these were successful (Table 1). Unsuccessful penetrations were all due to hard or sandy bottom. The stations can be divided into three groups with respect to relative positions to the Mendaña Fracture Zone (Fig. 1), which is thought to be spreading in the direction parallel to the Peru Trench (Warsi and Hilde, 1987). The first group consists of HF2 to HF6, which were located between the Peru Trench and the continent around $12^{\circ} \mathrm{S}$, south of the fracture zone. The second one is HF7 at the bottom of the trench, where the Mendaña Fracture Zone is subducting. The stations of the last group, HF8 and HF9, were located landward of the trench and at the trench bottom around $9^{\circ} \mathrm{S}$, north of the fracture zone.

We used a 4.5 -m-long Ewing-type probe with six thermistor sensors to measure geothermal gradients. A strong lance and acoustic-data telemetering capability permitted us to make multiple penetrations. Resolution of temperature variations using this instrument was about $0.001 \mathrm{~K}$. Temperature records obtained just above the seafloor were treated as reference points for temperatures measured in the sediments. 
Table 1. Results of heat-flow measurements during the MW8506 cruise.

\begin{tabular}{rcccccccc}
\hline Station & $\begin{array}{c}\text { Latitude } \\
(\mathrm{S})\end{array}$ & $\begin{array}{c}\text { Longitude } \\
(\mathrm{W})\end{array}$ & $\begin{array}{c}\text { Water } \\
\text { depth } \\
(\mathrm{m})\end{array}$ & $\begin{array}{c}\mathrm{PEN} \\
(\mathrm{m})\end{array}$ & $\mathrm{N}$ & $\begin{array}{c}\mathrm{G} \\
(\mathrm{mK} / \mathrm{m})\end{array}$ & $\begin{array}{c}\mathrm{K} \\
(\mathrm{W} / \mathrm{m} \cdot \mathrm{K})\end{array}$ & $\begin{array}{c}\mathrm{Q} \\
\left(\mathrm{mW} / \mathrm{m}^{2}\right)\end{array}$ \\
\hline HF2A & $11^{\circ} 29.1^{\prime}$ & $78^{\circ} 22.3^{\prime}$ & 1435 & 2.5 & 3 & & & \\
2B & $1^{\circ} 28.9^{\prime}$ & $78^{\circ} 38.7^{\prime}$ & 1440 & 2 & 3 & & & \\
HF3A & $11^{\circ} 17.4^{\prime}$ & $78^{\circ} 38.5^{\prime}$ & 2205 & 3 & 3 & & & \\
3C & $11^{\circ} 15.5^{\prime}$ & $78^{\circ} 38.7^{\prime}$ & 2185 & 2.5 & 3 & & & \\
3D & $11^{\circ} 15.3^{\prime}$ & $78^{\circ} 39.0^{\prime}$ & 2185 & 2.5 & 3 & & & \\
HF4A & $11^{\circ} 25.5^{\prime}$ & $78^{\circ} 45.4^{\prime}$ & 2490 & 4 & 5 & 53 & 0.79 & 42 \\
4D & $1^{\circ} 24.6^{\prime}$ & $78^{\circ} 45.4^{\prime}$ & 2490 & 3 & 4 & 51 & 0.79 & 40 \\
4F & $1^{\circ} 24.8^{\prime}$ & $78^{\circ} 45.9^{\prime}$ & 2520 & 4 & 5 & 52 & 0.79 & 41 \\
4G & $11^{\circ} 24.9^{\prime}$ & $7^{\circ} 45.9^{\prime}$ & 2520 & 4 & 5 & 54 & 0.79 & 42 \\
4H & $11^{\circ} 25.5^{\prime}$ & $78^{\circ} 47.9^{\prime}$ & 2585 & 3 & 4 & 45 & 0.79 & 35 \\
HF6B & $11^{\circ} 09.1^{\prime}$ & $79^{\circ} 12.7^{\prime}$ & 3930 & 4 & 5 & 50 & $0.98^{*}$ & 49 \\
6E & $11^{\circ} 08.5^{\prime}$ & $79^{\circ} 12.0^{\prime}$ & 3955 & 4.5 & 5 & 50 & $0.98^{*}$ & 49 \\
HF7A & $10^{\circ} 19.7^{\prime}$ & $80^{\circ} 01.5^{\prime}$ & 6270 & 5 & 5 & 21 & $0.86^{*}$ & 18 \\
7B & $10^{\circ} 21.5^{\prime}$ & $80^{\circ} 00.7^{\prime}$ & 6265 & 5 & 5 & 42 & $0.86^{*}$ & 36 \\
7C & $10^{\circ} 25.4^{\prime}$ & $79^{\circ} 58.7^{\prime}$ & 6275 & 5 & 5 & 8 & $0.86^{*}$ & 7 \\
HF8A & $9^{\circ} 25.7^{\prime}$ & $80^{\circ} 07.0^{\prime}$ & 2640 & 4.5 & 4 & 50 & 0.82 & 41 \\
8B & $9^{\circ} 26.1^{\prime}$ & $80^{\circ} 10.1^{\prime}$ & 3080 & 5 & 4 & 40 & 0.82 & 32 \\
8C & $9^{\circ} 24.3^{\prime}$ & $80^{\circ} 15.8^{\prime}$ & 3895 & 4.5 & 4 & 56 & 0.82 & 46 \\
HF9A & $9^{\circ} 01.1^{\prime}$ & $80^{\circ} 33.6^{\prime}$ & 4410 & 4.5 & 4 & 45 & $0.82^{*}$ & 37 \\
9G & $9^{\circ} 06.3^{\prime}$ & $80^{\circ} 44.6^{\prime}$ & 6220 & 1 & 2 & 34 & $0.86^{*}$ & 29 \\
\hline
\end{tabular}

Alphabetical suffixes of the station names are used to distinguish multiple penetrations. At HF2 and HF3, temperature gradients cannot be determined as the temperature profiles are nonlinear. $\mathrm{PEN}=$ the estimated penetration of the lowermost active thermistor; $\mathrm{N}=$ the number of active thermistors in mud; $\mathrm{G}=$ the temperature gradient; $\mathrm{K}=$ the thermal conductivity ( ${ }^{*}$ represents values measured at nearby stations); and $Q=$ the heat flow.

Temperature variations of thermistor probes after penetration are described by the function $\mathrm{F}(\alpha, \tau)$ of Bullard (1954). As the thermal time constant of our sensor probes ( $3.5 \mathrm{~mm}$ in diameter) is very short, the $\mathrm{F}(\alpha, \tau)$ function was approximated by the inverse of time after penetration in calculating the equilibrium temperatures. The error in the relative temperature between the thermistors was estimated as 0.003 to $0.005 \mathrm{~K}$.

The obtained temperature vs. depth profiles are shown in Figure 2. The penetration depth of the lowermost active thermistor in Table 1 was estimated from the temperature profile and the bottom-water temperature measured after pulling out. Temperature gradients were determined by the least-squares fit to straight lines. Solid lines in Figure 2 represent the best-fitted gradients, and the obtained values are presented in Table 1 . At HF2 and HF3, the temperature profiles are nonlinear, probably due to temporal variation of the bottom-water temperature; hence, we discarded data at these stations. At HF4, temperature profiles are linear, if we ignore the uppermost sensor. At HF6, HF7, and HF9, the temperature data of the sensors shown by triangles were excluded from the least-squares fit, as they consistently showed high values. This tendency might result from insufficient azimuthal spacing of the outriggers (Davis et al., 1984).

Thermal conductivities of the sediments were measured using the needle probe technique (Von Herzen and Maxwell, 1959 ) on samples taken by a gravity corer (Table 2 ). The values measured on board the Moana Wave were corrected to in-situ temperature and pressure conditions, according to Ratcliffe (1960). The obtained values are plotted vs. depth in Figure 3 . Although there are several thin high conductivity layers, these are much thinner than the interval of temperature sensors (about $80 \mathrm{~cm}$ ) and it may be that these are not reflected in the temperature profiles. Thus, we used the average values (Table 2) for calculating heat flow (Table 1). At those stations where no core samples were taken, thermal conductivities were estimated from the values measured in the vicinity. Errors in heat-flow values were estimated as about $15 \%$.

\section{Measurements in Drill Holes}

Leg 112 provided unique opportunities for geothermal studies in the Peru margin area (Fig. 1). Temperature measurements in deep drill holes make it possible for us to compare the results with the surface heat flow obtained by normal probes and the sediment temperature inferred from gas hydrate BSRs. These measurements are especially valuable in shallow sea areas. It is usually difficult to determine heat flow with an ordinary heat-flow probe in shallow sea areas, as the temperature profiles in surface sediments are affected by temporal variations in bottom-water temperature. Results of the MW8506 cruise suggest that in the Peru margin, heat flow may not be determined with a surface probe in the area where water depth is less than about $2500 \mathrm{~m}$.

During Leg 112, temperatures in the drill holes were measured by three different methods. First, the von Herzen advanced piston corer (APC) heat-flow instrument (Horai and Von Herzen, 1985) was used when APC cores of soft sediments were taken. A small tool was installed in the cutting shoe of the APC and kept in undisturbed sediment for about 10 min. The equilibrium temperature was calculated from the decay curve of frictional heat generated by penetration, following the theory of Horai and Von Herzen (1985).

Second, the T-probe was used with the Barnes pore-water sampler (Yokota et al., 1980) in deeper layers. Sediment temperature was recorded for 20 to $\mathbf{4 0}$ min during pore-water sampling. The equilibrium temperature was extrapolated from the record, according to Bullard (1954). This probe was run together with the APC tool for calibrating the characteristics of two different instruments.

The third method was estimation from wireline logging data. Temperature logging was performed twice in logged holes. Equilibrium formation temperatures were extrapolated 


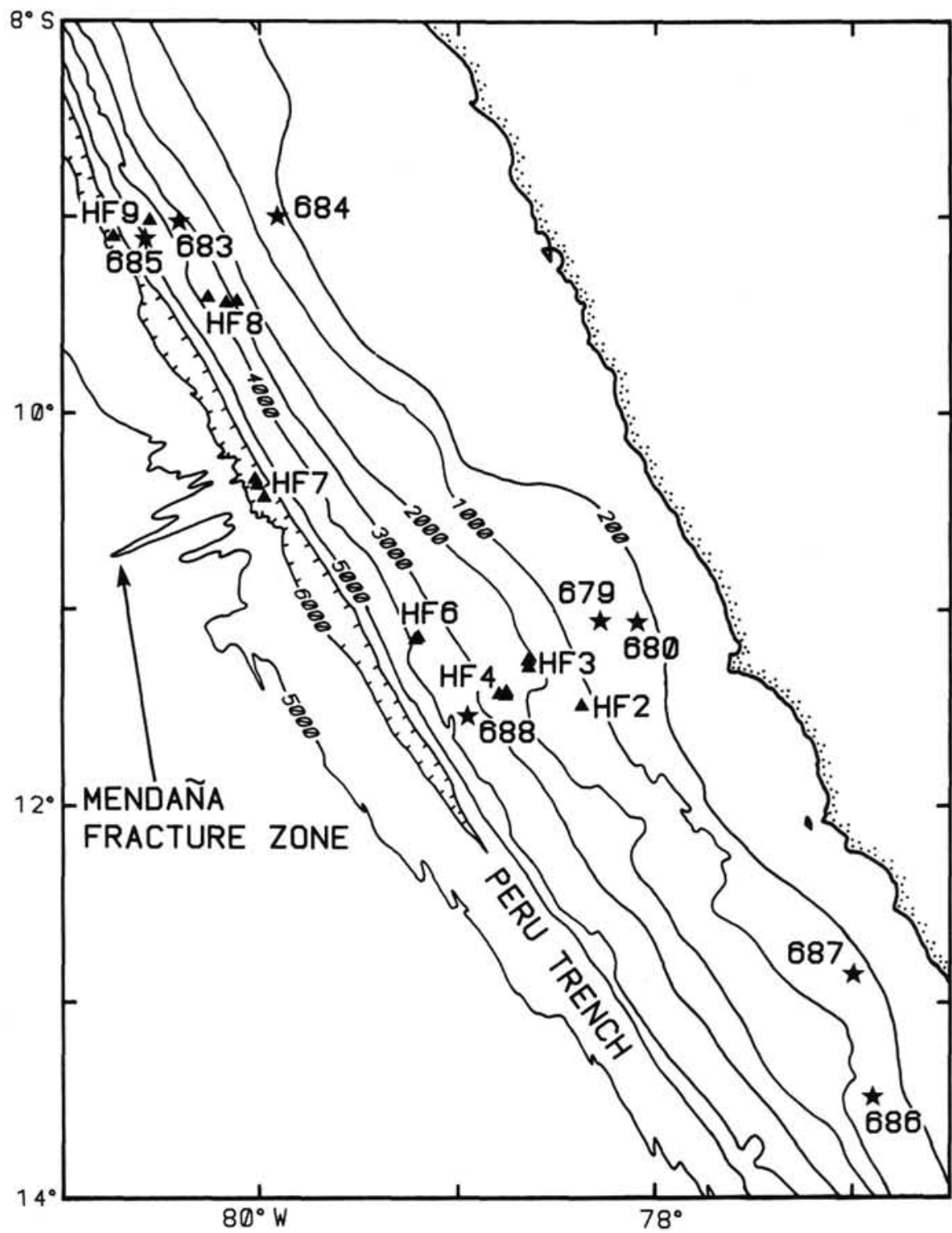

Figure 1. Locations of the successful heat-flow stations during the MW8506 cruise (triangles) and the ODP Leg 112 sites where heat-flow values were obtained (stars).

from the temperatures at two different times after circulation was stopped using Lachenbruch and Brewer's method (1959). These three methods are described in detail in the "Explanatory Notes" chapter of Suess, von Huene, et al. (1988).

Thermal conductivity was measured on recovered samples using the needle-probe method (see "Explanatory Notes" chapter, Suess, von Huene, et al., 1988). Temperature and pressure effects were corrected following Ratcliffe (1960). In some holes, thermal conductivity could not be measured in the depth ranges necessary for calculating heat flow because the samples were too disturbed. In such cases, thermal conductivity was estimated from the water content, based on the relationship between thermal conductivity and water content in Leg 112 samples ("Physical Properties" section, "'Site 688' chapter, Suess, von Huene, et al., 1988). Thermal conductivity was also estimated from wireline logging data using Ocola's method (1985) ("Explanatory Notes" chapter, Suess, von Huene, et al., 1988).

Results of temperature measurements and quality of the obtained heat-flow data (Table 3 ) are briefly reviewed as follows. Details were reported in site chapters of Suess, von
Huene, et al. (1988). Heat flow could not be determined at Sites 681 and 682 .

Site 679: Temperature vs. depth profile was estimated from the wireline logging data in Hole 679E. Quality of data is not high because the final temperature was estimated from only two logging runs separated by a short time interval.

Site 680: Temperature was determined with the APC tool at 34.0 meters below seafloor (mbsf) of Hole 680B and at 24.8 mbsf of Hole $680 \mathrm{C}$. Heat flow was calculated assuming that the sub-bottom depth of each hole was equivalent. The error is large because the temperature difference is small, as compared to errors in each equilibrium temperature.

Site 683: Only one measurement was obtained with the APC tool at 40.2 mbsf. Heat flow was calculated by using the bottom-water temperature based on oceanographic data.

Site 684: The APC tool gave temperature data at two depths: 33.8 and 52.8 mbsf. Errors in the equilibrium temperatures are large, while the depth range used to calculate heat flow is small, so that heat flow could not be determined well.

Site 685: Temperature was determined from the wireline logging data for the depth range of 75 to $150 \mathrm{mbsf}$, and heat 
TEMPERATURE $\left({ }^{\circ} \mathrm{C}\right)$

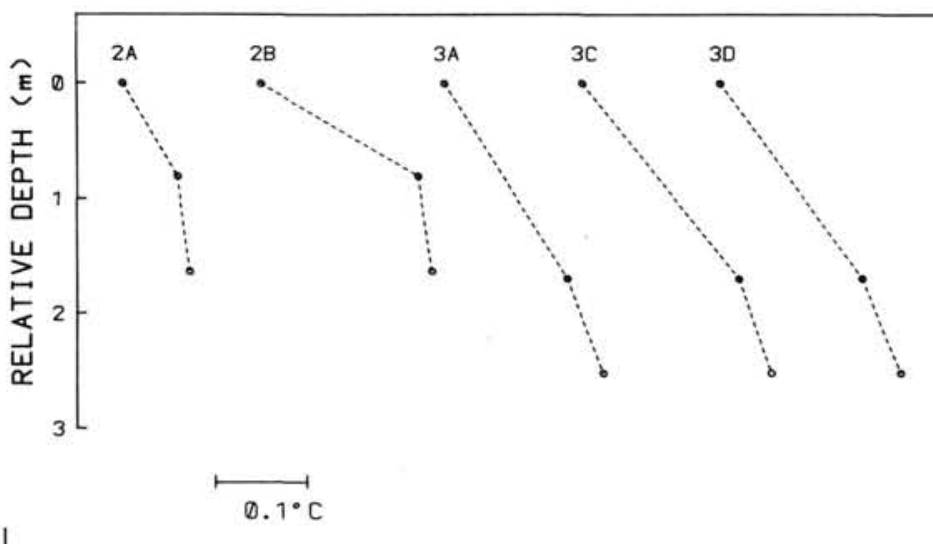

TEMPERATURE ( $\left.{ }^{\circ} \mathrm{C}\right)$

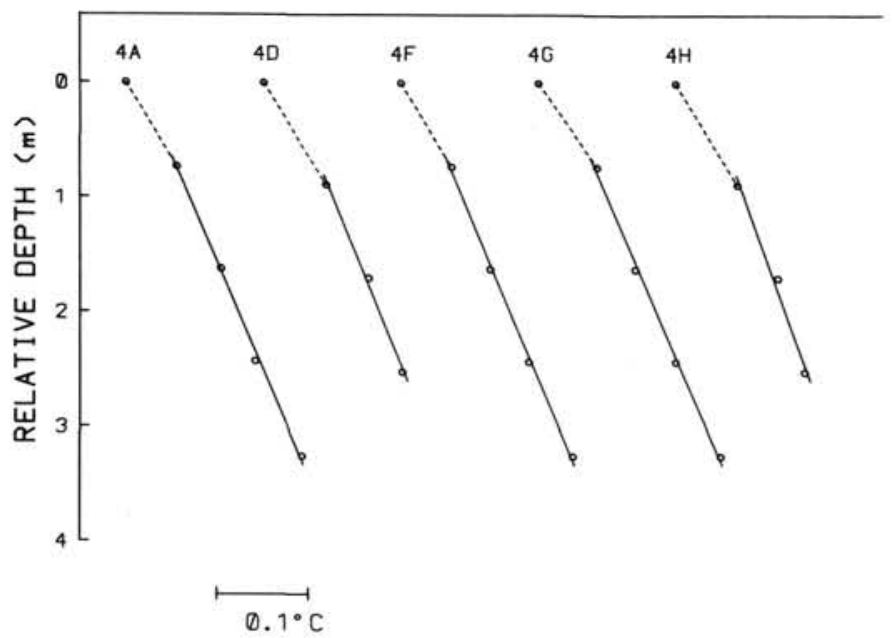

TEMPERATURE $\left({ }^{\circ} \mathrm{C}\right)$
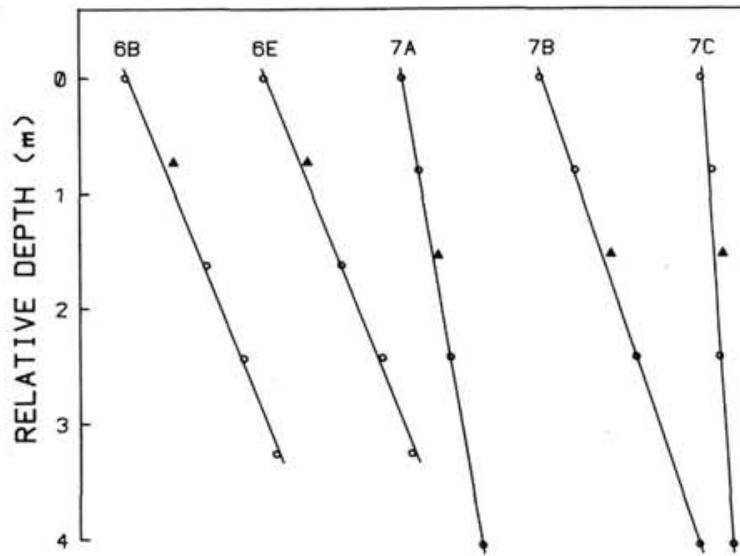

$\stackrel{\longrightarrow .1^{\circ} \mathrm{C}}{ }$

TEMPERATURE $\left({ }^{\circ} \mathrm{C}\right)$

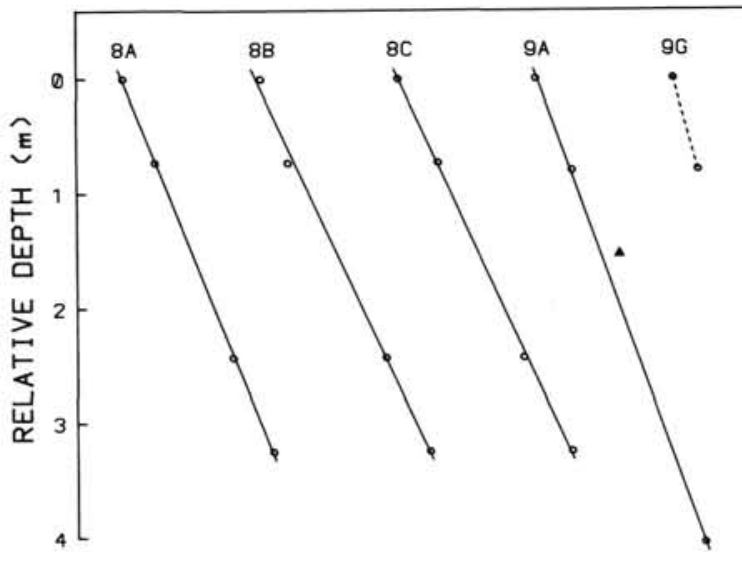

$\stackrel{\sim}{0.1^{\circ} \mathrm{C}}$

Figure 2. Temperature vs. depth profiles obtained during the MW8506 cruise. Solid lines are the least-square fits to straight lines. Triangles represent data that were not used to calculate temperature gradients.

flow was estimated at about $28 \mathrm{~mW} / \mathrm{m}^{2}$. Combined with the bottom-water temperature, heat flow from 0 to 75 mbsf was calculated as $41 \mathrm{~mW} / \mathrm{m}^{2}$.

Site 686: Two temperature datums from the APC tool and one datum using the T-probe were obtained. Because these temperatures were determined with a large depth interval (from 33.6 to $186.7 \mathrm{mbsf}$ ), the quality of data is high.

Site 687: Temperature was determined at two depths with the APC tool and at one depth with the T-probe. The heat-flow value has a large error since sufficient thermal conductivity and water content data could not be obtained because of the very sandy and disturbed state of samples.

Site 688: Heat flow was determined from one APC Tool temperature ( $36.8 \mathrm{mbsf}$ ) and from the bottom-water temperature, based on the oceanographic data.

In general, only few temperature data could be obtained at each site. This is partly because the instruments for measuring temperatures did not work properly during the first part of the leg, but mainly because the sediments were too stiff to risk leaving the APC core barrel undisturbed for the desired $10 \mathrm{~min}$ or to allow the pore-water sampler to penetrate. In the future, an instrument may have to be developed that can be used for stiff sediments. Another problem is that the pore-pressure
Table 2. Results of thermal-conductivity measurements during the MW8506 cruise.

\begin{tabular}{cccccc}
\hline Station & $\begin{array}{c}\text { Latitude } \\
(\mathrm{S})\end{array}$ & $\begin{array}{c}\text { Longitude } \\
(\mathrm{W})\end{array}$ & $\begin{array}{c}\text { Water depth } \\
(\mathrm{m})\end{array}$ & $\begin{array}{c}\text { LEN } \\
(\mathrm{m})\end{array}$ & $\begin{array}{c}\mathrm{K} \\
(\mathrm{W} / \mathrm{m} \cdot \mathrm{K})\end{array}$ \\
\hline G-10 & $11^{\circ} 18.0^{\prime}$ & $78^{\circ} 37.4^{\prime}$ & 2210 & 3.81 & $0.82 \pm 0.08$ \\
G-13 & $11^{\circ} 24.7^{\prime}$ & $78^{\circ} 45.5^{\prime}$ & 2495 & 3.32 & $0.79 \pm 0.04$ \\
G-29 & $9^{\circ} 24.7^{\prime}$ & $80^{\circ} 07.3^{\prime}$ & 2590 & 2.92 & $0.82 \pm 0.05$ \\
\hline
\end{tabular}

$\mathrm{LEN}=$ the length of the obtained core; and $\mathrm{K}=$ the average thermal conductivity and the standard deviation.

probe for the pore-water sampler has no temperature sensor, so that we could not measure temperature with the T-probe in holes where pore pressure was measured. A probe will need to be developed that can measure both temperature and porewater pressure.

In the middle to lower slope, where we could determine heat flow with a surface probe, reliable values were obtained only at Sites 683 and 688. At these sites, the heat flow determined from depth ranges of 0 to about $40 \mathrm{mbsf}$ is consistent with results of surface measurements at almost equivalent positions on the slope (Figs. 4 and 5). This indi- 


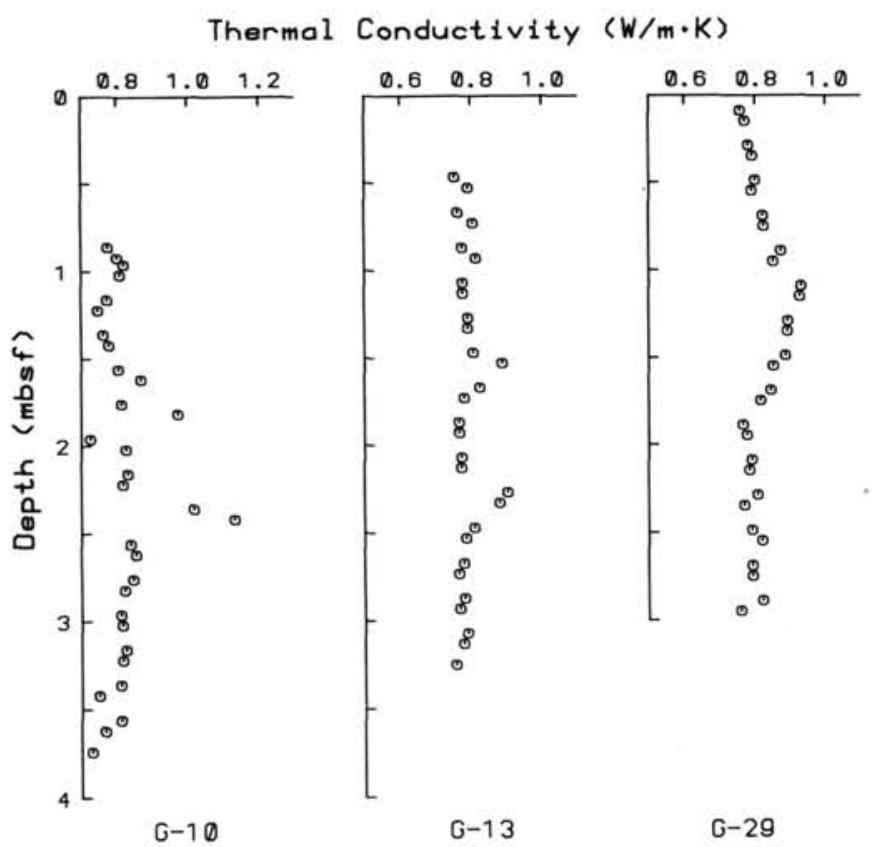

Figure 3 . Thermal conductivity vs. depth profiles measured on gravity core samples collected during the MW8506 cruise.

Table 3. Heat-flow data obtained from temperature measurements in Leg 112 drill holes.

\begin{tabular}{lccccc}
\hline \multicolumn{1}{c}{ Hole } & $\begin{array}{c}\text { Latitude } \\
(\mathrm{S})\end{array}$ & $\begin{array}{c}\text { Longitude } \\
(\mathrm{W})\end{array}$ & $\begin{array}{c}\text { Water depth } \\
(\mathrm{m})\end{array}$ & $\begin{array}{c}\mathrm{DR} \\
(\mathrm{mbs})\end{array}$ & $\begin{array}{c}\mathrm{Q} \\
\left(\mathrm{mW} / \mathrm{m}^{2}\right)\end{array}$ \\
\hline $679 \mathrm{E}$ & $11^{\circ} 03.78^{\prime}$ & $78^{\circ} 16.34^{\prime}$ & 462 & $90-240$ & $25-30$ \\
$680 \mathrm{~B}, 680 \mathrm{C}$ & $11^{\circ} 03.90^{\prime}$ & $78^{\circ} 04.67^{\prime}$ & 253 & $25-34$ & $20-70$ \\
$683 \mathrm{~A}$ & $9^{\circ} 01.69^{\prime}$ & $80^{\circ} 24.40^{\prime}$ & 3072 & $0-42$ & 39 \\
$684 \mathrm{~A}$ & $8^{\circ} 59.59^{\prime}$ & $79^{\circ} 54.35^{\prime}$ & 426 & $34-53$ & $10-50$ \\
$685 \mathrm{~A}$ & $9^{\circ} 06.78^{\prime}$ & $80^{\circ} 35.0^{\prime}$ & 5071 & $0-150$ & $30-40$ \\
$686 \mathrm{~A}$ & $13^{\circ} 28.81^{\prime}$ & $76^{\circ} 53.49^{\prime}$ & 447 & $34-187$ & 45 \\
$687 \mathrm{~A}$ & $12^{\circ} 51.78^{\prime}$ & $76^{\circ} 59.43^{\prime}$ & 307 & $36-169$ & $50-70$ \\
$688 \mathrm{~A}$ & $11^{\circ} 32.26^{\prime}$ & $78^{\circ} 56.57^{\prime}$ & 3820 & $0-37$ & 46 \\
\hline
\end{tabular}

$\mathrm{DR}=$ the sub-bottom depth range that was used for calculating heat flow; and $Q=$ the heat flow.

cates that the conductive heat flow is constant with depth from 0 to 40 mbsf at these sites.

\section{Estimating from Gas Hydrate BSRs}

On the landward slope of the Peru Trench, BSRs with reflection polarity reversals are often seen in seismic-reflection profiles (e.g., Lehner et al., 1983; von Huene et al., 1985). Such BSRs are interpreted as the bases of gas-hydrate layers in sediments. Gas hydrates were indeed sampled during Leg 112 at Sites 685 and 688, which are only a few kilometers from the locations where BSRs were observed ("Organic Geochemistry" sections, Sites 685 and 688 chapters, Suess, von Huene, et al., 1988). Existence of gas hydrates was also indicated by wireline logging data at Site 685 , which showed anomalies in velocity, resistivity, and density ("Logging" section, Site 685 chapter, Suess, von Huene, et al., 1988).

Because such gas hydrate BSRs represent the phase boundary between gas plus water and gas hydrate, the depths of BSRs provide information about temperature in sediments. Using the velocity-density and the velocity-thermal conductivity relationships for marine sediments, one can estimate the heat flow from the depths of BSRs (Yamano et al., 1982). This method was applied to several areas, such as the Middle
America Trench (Yamano et al., 1982), the Nankai Trough (Yamano et al., 1984), and the Chile Trench (Cande et al., 1987). The heat-flow values obtained agreed well with those measured using surface heat-flow probes.

Recently, numbers of seismic-reflection profiles were obtained in the Peru Trench area (von Huene and Miller, 1988; Bourgois et al., 1988). Many BSRs were observed in these seismic records in the lower slope area. Figure 6 shows an example of prominent BSRs on a profile at about $11^{\circ} 14^{\prime} \mathrm{S}$ $78^{\circ} 49^{\prime} \mathrm{W}$. Between $11^{\circ}$ and $12^{\circ} \mathrm{S}$, the BSRs are concentrated in two different water depth ranges, about $4000 \mathrm{~m}$ and about 2000 m (Fig. 5).

One should know the velocity structure of sediment layers to estimate heat flow. We used the general velocity structure for the Peru margin area determined from wireline logging data and shipboard measurements from Leg 112 ("Geophysics" section, Site 685 chapter, Suess, von Huene, et al., 1988). From the velocity structure, density and thermal conductivity structures can be obtained using the velocity-density relationship of Hamilton (1978) and the velocity-thermal conductivity relationship of Horai (1982), respectively. Using these physical properties, heat flow was estimated from the depths of BSRs (termed "gas hydrate heat flow" below). We used the phase diagram for $\mathrm{CH}_{4}$ plus $3 \% \mathrm{NaCl}$ as the phase boundary because analyses of gas hydrates obtained at Sites 685 and 688 showed that almost all of the included gas was $\mathrm{CH}_{4}$ ("Organic Geochemistry" sections, Sites 685 and 688 chapters, Suess, von Huene, et al., 1988).

The general velocity structure may not be applicable to all the BSRs. Small errors in velocity, however, do not affect the estimated heat flow much. A higher velocity gives a greater depth to the BSR, and thus, a lower geothermal gradient, but a higher velocity also gives a higher thermal conductivity. As a result, a higher velocity by $0.2 \mathrm{~km} / \mathrm{s}$ leads to a higher heat flow by only 2 to $4 \mathrm{~mW} / \mathrm{m}^{2}$ in the present cases. The error in the estimated heat flow mainly comes from the uncertainty in the velocity-thermal conductivity relationship and may reach $25 \%$.

Our obtained values are shown in Figure 5 . Note that these values may have errors of 10 to $20 \mathrm{~mW} / \mathrm{m}^{2}$. However, relative variation in gas-hydrate heat flow must be more reliable, when we consider only the shallower area (about $2000 \mathrm{~m}$ ) or only the deeper area (about $4000 \mathrm{~m}$ ). Heat-flow values obtained by the other methods are also shown in Figure 5 for comparison. Between $11^{\circ}$ and $12^{\circ} \mathrm{S}$, the gas-hydrate heat flow agrees with the results of measurements at the surface and in a drill hole in the deeper area. The gas-hydrate heat flow is somewhat higher than the surface values in the shallower area, but the difference is within the limits of errors.

\section{HEAT-FLOW DISTRIBUTION}

The new heat-flow data presented above and obtained during the SEAPERC cruise of the Jean-Charcot (Pautot et al., 1986; J. Bourgois, pers. comm., 1988) enabled us to map the heat-flow distribution in the central Peru margin in detail (Figs. 4 and 5).

Heat flow is generally 40 to $50 \mathrm{~mW} / \mathrm{m}^{2}$ on the landward slope of the Peru Trench. The exception is $114 \mathrm{~mW} / \mathrm{m}^{2}$ at $12^{\circ} 49^{\prime} \mathrm{S}, 77^{\circ} 53^{\prime} \mathrm{W}$. However, this value was obtained at a water depth of $2260 \mathrm{~m}$, and our experience during this study suggests that heat flow measured in the area shallower than $2500 \mathrm{~m}$ may have been affected by temporal variation in the bottom-water temperature.

At the bottom of the trench, heat flow is low (lower than 40 $\mathrm{mW} / \mathrm{m}^{2}$ ) and variable. It is scattered, especially where the Mendaña Fracture Zone is subducting. Just before subduction, i.e., seaward of the trench axis, heat flow is extremely 


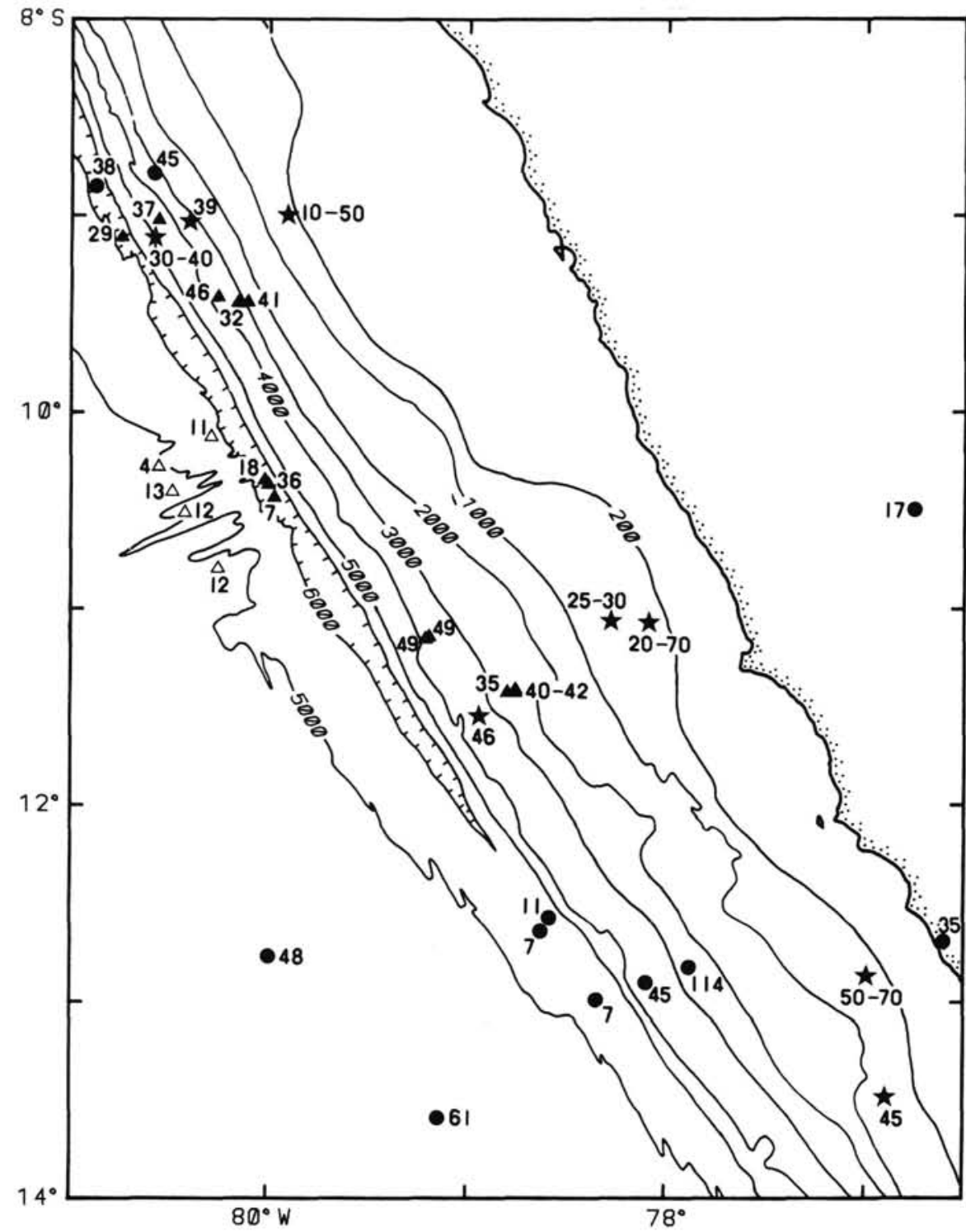

Figure 4. Heat-flow data in the central Peru Trench area (in $\mathrm{mW} / \mathrm{m}^{2}$ ). Circles represent the previous data (Von Herzen, 1959; Von Herzen and Uyeda, 1963; Henry and Pollack, 1988). Closed and open triangles are the data obtained during the MW8506 cruise and a cruise of the Jean-Charcot in 1986 (J. Bourgois, pers. comm., 1988), respectively. Stars represent the values determined at the Leg 112 sites.

low in the fracture zone. Heat flow at the trench bottom north of the Mendaña Fracture Zone is 29 to $38 \mathrm{~mW} / \mathrm{m}^{2}$ and may be higher than that south of the fracture zone $\left(7\right.$ to $\left.11 \mathrm{~mW} / \mathrm{m}^{2}\right)$. However, we need more data to examine this tendency.

We plotted heat flow vs. distance from the trench axis (Fig. 7). Between 10 and $30 \mathrm{~km}$ from the trench axis, the gashydrate heat flow shows a landward increase. We postulate that the relative accuracy of the gas-hydrate heat flow is rather high in this small area (cf. Fig. 5) and that the landward increase is probably true. The gas-hydrate heat flow is higher in the shallower area ( 60 to $80 \mathrm{~km}$ from the trench axis) than in the deeper area (10 to $30 \mathrm{~km})$. Hence, the gas-hydrate heat flow appears to increase landward from 10 to about $60 \mathrm{~km}$ from the axis. The surface heat-flow data between 30 and 60 $\mathrm{km}$, however, do not follow this trend. Possibly, the gashydrate heat flow in the shallower area was estimated systematically higher than the true heat flow because of errors when estimating thermal conductivity.
The most landward data in Figure $7\left(35 \mathrm{~mW} / \mathrm{m}^{2}\right)$ were measured on the coast (cf. Fig. 4). Thus, low heat flow may extend to the coast. There are few heat-flow data in the Andes of central and northern Peru, where a long volcanic gap exists, and they are low, 17 to $55 \mathrm{~mW} / \mathrm{m}^{2}$, except for one value, 196 $\mathrm{mW} / \mathrm{m}^{2}$ (Uyeda et al., 1980; Henry and Pollack, 1988). It is important to obtain more data to determine whether the high heat flow is a local anomaly.

\section{DISCUSSION}

We can compare the heat-flow profile from the axis of the Peru Trench to the coast with profiles across other subduction zones (e.g., Blackwell et al., 1982; Yamano and Uyeda, 1988) and discuss characteristics of the central Peru subduction zone.

\section{Low Heat Flow at the Bottom of the Trench}

The most evident feature of the Peru subduction zone is the low heat flow at the trench axis and seaward of the trench. 

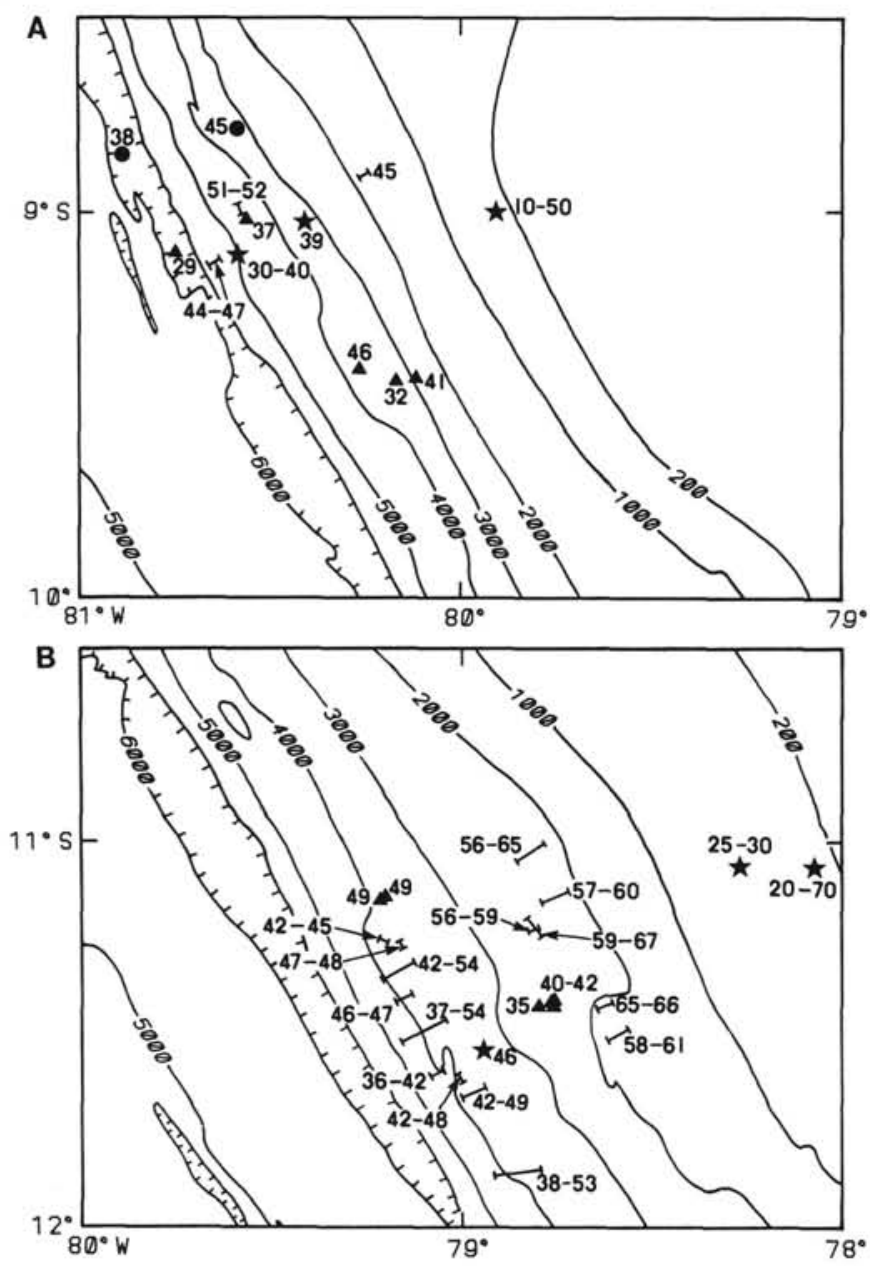

Figure 5. Seismic-reflection lines along which gas-hydrate BSRs were observed and heat flow estimated from the depths of the BSRs (in $\mathrm{mW} / \mathrm{m}^{2}$ ). Heat-flow values determined by surface measurements and measurements in the Leg 112 drill holes are also shown in the same way as in Figure 4. A. Northern area. B. Southern area.

Although sporadic low heat-flow data exist at the bottoms and seaward of other trenches, heat flow consistently lower than $20 \mathrm{~mW} / \mathrm{m}^{2}$ is anomalous.

The thermal effect of subduction should be small seaward of trenches; thus, heat flow is thought to be determined mainly by the age of subducting oceanic lithosphere. The low heatflow values seaward of the Peru Trench were measured in the Mendaña Fracture Zone. Warsi et al. (1983) proposed that the Mendana Fracture Zone is the locus of a seaward-propagating rift, and Warsi and Hilde (1987) identified magnetic lineations parallel to the fracture zone as anomalies 1 through $2 \mathrm{~A}$, which correspond to ages of 0 to $3 \mathrm{Ma}$. In such a young oceanic crust, hydrothermal circulation may be taking place as in mid-ocean ridge areas (e.g., Lister, 1972). Considering that the ridges in the fracture zone are not covered by sediments (Warsi et al., 1983), it is probable that most of the heat from the deep is flowing out from the exposed ridges advectively, so that the conductive heat flow measured in sediment ponds is extremely low.

Stations HF7A to HF7C of this study are located at the trench axis near anomaly $2 \mathrm{~A}$ of the Mendaña Fracture Zone. Accumulation of trench axis turbidites would seal the hydrothermal circulation, so that the conductive surface heat flow would increase and approach the heat flow from the deep.

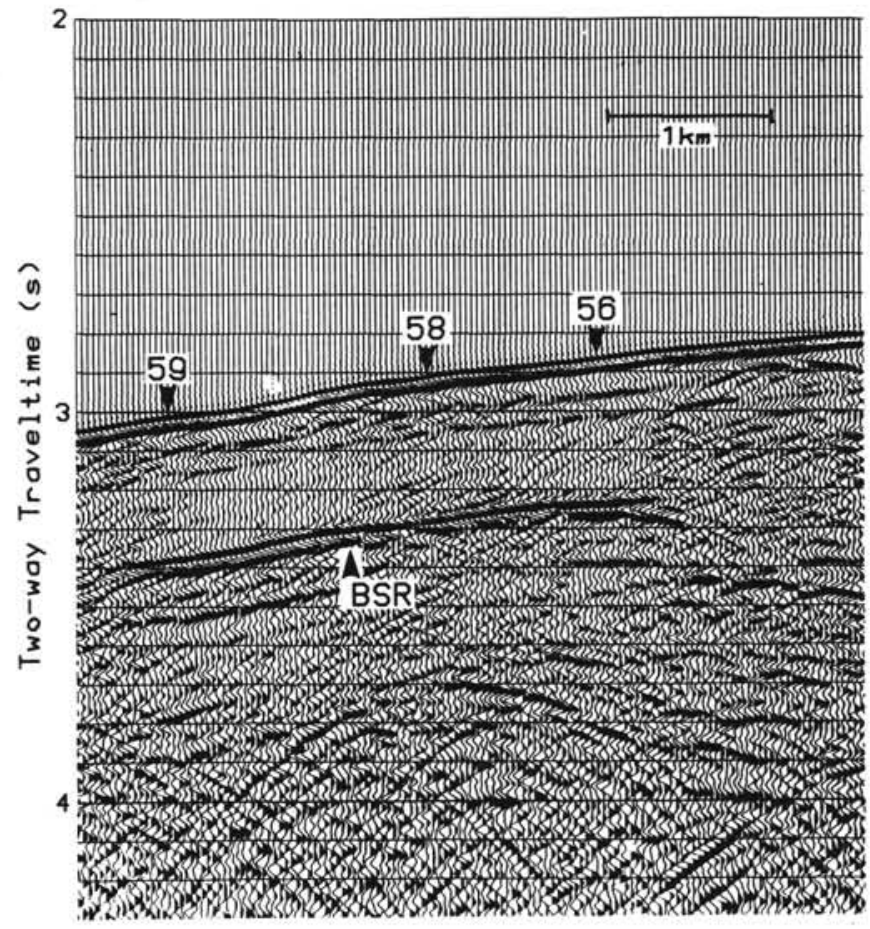

Figure 6. Example of a prominent BSR due to gas hydrates on a multichannel seismic-reflection profile at about $11^{\circ} 14^{\prime} \mathrm{S}, 78^{\circ} 49^{\prime} \mathrm{W}$ and heat-flow values estimated from the BSR (in $\mathrm{mW} / \mathrm{m}^{2}$ ). Note the reversal of polarity between seafloor and the BSR caused by a reversal in velocity between sediment whose pore-space is filled with solid gas hydrate above and sediment whose pore-space is filled with fluid and free gas below.

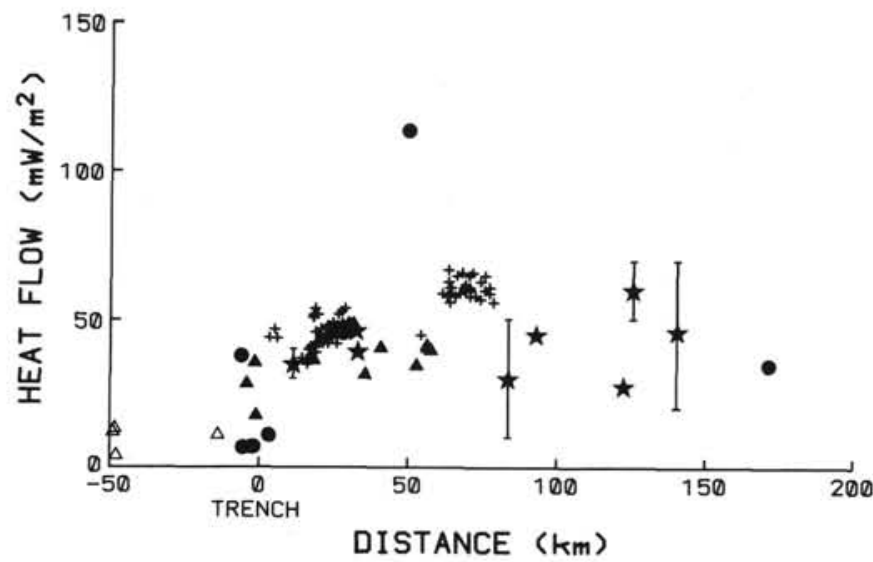

Figure 7. Heat flow vs. distance from the trench axis across the central Peru subduction zone. The positive distance means landward of the trench. Notation is the same as in Figure 4. Crosses represent the gas hydrate heat flow. Note that the gas-hydrate heat flow has errors of 10 to $20 \mathrm{~mW} / \mathrm{m}^{2}$.

However, values actually measured $\left(7\right.$ to $\left.36 \mathrm{~mW} / \mathrm{m}^{2}\right)$ are much lower than expected from the age of the subducting plate, according to Warsi and Hilde (1987) (about $300 \mathrm{~mW} / \mathrm{m}^{2}$ ).

These low heat-flow values may indicate that new seafloor has not been created in the Mendaña Fracture Zone, but may also suggest that conductive recovery has not been fully attained at the trench axis. The rate of recovery depends on the thickness of the layer, which was cooled by hydrothermal circulation much more than by pure conduction. It may possibly take $0.4 \mathrm{~m} . \mathrm{y}$. or more to provide a significant increase 
in heat flow if the thickness of the circulation layer is about 6 $\mathrm{km}$ (Hobart et al., 1985). A large variation in the observed heat flow also implies that thermal disturbance by hydrothermal circulation still remains. In other trenches where young plates are subducting, such as the Nankai Trough, the Chile Trench, and off Oregon, high heat-flow values have been reported. In these trenches, sediment covers have developed to some extent before the plates reach the trenches, so that the conductive recovery may have been almost attained (e.g., Nagihara et al., 1989).

A further decrease in surface heat flow may result from rapid sedimentation. Surface heat flow is reduced by about $40 \%$ if 500 -m-thick turbidites are deposited in 50,000 yr. This effect can thus partly explain the low heat-flow values observed. It is also possible that the heat-flow stations are at the southern margin of the Mendaña Fracture Zone rifting, not on a new oceanic crust. If this is the case, the true heat flow from the deep should be lower than $300 \mathrm{~mW} / \mathrm{m}^{2}$. To examine these possibilities, it will be necessary to conduct more detailed heat-flow measurements both in the Mendaña Fracture Zone and along the trench axis, where the fracture zone is subducted.

The age of the subducting Nazca Plate is about 30 Ma north of the fracture zone and about $40 \mathrm{Ma}$ south of it. The heat flow expected from the age is about 90 and $80 \mathrm{~mW} / \mathrm{m}^{2}$, respectively. Thus, the heat flow measured at the bottom of the trench is again too low. The low heat flow at around $9^{\circ} \mathrm{S}$ may be explained by the effect of sedimentation. The extremely low heat flow near $13^{\circ} \mathrm{S}$ is anomalous because there are no thick turbidite layers (Warsi et al., 1983) and requires some cooling process other than sedimentation effect. A possible cooling mechanism is water flow along normal faults, which dissect the oceanic basement, on the seaward trench slope.

\section{Landward Slope}

On the landward slope of the Peru Trench, venting of pore fluids through sediment layers was indicated by living giant white clams that were dredged up (Kulm et al., 1986), by fluid-escape structures in the Leg 112 cores, and by the negative chloride anomaly at Sites 683 and 688 (Shipboard Scientific Party, 1988). Such fluid venting can affect the surface heat flow. On the Oregon accretionary complex, anomalously high heat-flow values were observed and are thought to be associated with fluid venting (Langseth and Hobart, 1984). The higher heat flow from 0 to 75 mbsf than from 75 to 150 mbsf at Site 685 might result from upward flow of pore water from the accretionary complex. It is also probable that the steep increase in heat flow just landward of the trench axis is partly due to redistribution of heat flux by fluid flow.

The heat-flow distribution on the landward slope may be affected by various subduction parameters. The ages of subducting lithosphere are different by about $10 \mathrm{Ma}$ between the north and south of the Mendaña Fracture Zone. The subsidence history in the forearc basin is also different between the north and south, indicating a difference in the tectonic stress field (Shipboard Scientific Party, 1988). On the lower slope, however, the heat flow in the north is similar to that in the south, and we cannot compare the heat flow from the upper slope to the coast because of lack of data in the north. The small difference in the age of the subducting plate is not reflected in the heat flow on the lower slope.

Yamano and Uyeda (1988) constructed heat-flow profiles across subduction zones with a reasonable amount of data and showed that the heat flow between the trenches and arcs is generally similar. Heat flow is relatively low and uniform in the seaward part of the arc-trench gap and increases toward the volcanic arc from some point between the arc and the trench. In the Peru subduction zone, we cannot tell whether the landward increase exist, as few data are on land. The low heat flow also prevails in the seaward part in the Peru subduction zone, but the value seems to be slightly higher than in other subduction zones. This value is 40 to $50 \mathrm{~mW} / \mathrm{m}^{2}$ in the Peru subduction zone, while it is about $30 \mathrm{~mW} / \mathrm{m}^{2}$ or lower in the northeast Japan subduction zone (Yamano et al., 1987), the Coast Range of Oregon (Blackwell et al., 1982), and southern Mexico (Ziagos et al., 1985).

The age of the subducting plate apparently cannot explain this difference, because the plates subducting off Oregon and southern Mexico are much younger than the Nazca Plate subducting at the Peru Trench. Wang et al. (1987) modeled thermal structures of subduction zones and attributed the higher heat flow in the Peru margin than in the Oregon margin to the difference in frictional heating along the boundary between the upper and lower plates. They maintained that excess pore pressures in the thick accretionary prism in the Oregon margin reduce the frictional heating and result in lower surface heat flow, while tectonic erosion was dominant until the recent geologic past in the Peru margin. This explanation, however, may not be applicable to all subduction zones. The heat flow is lower in the northeast Japan subduction zone, where the tectonic stress was tensional in the Neogene and the accretionary prism is small (von Huene et al., 1980), as in the Peru margin. On the other hand, the Nankai Trough, which has a well-developed accretionary complex, exhibits higher heat flow than in the Peru margin (Yamano et al., 1984).

Subduction of the Nazca Ridge may have affected the thermal structure of the Peru margin. One expects that frictional heating was larger and the upper plate was heated when the buoyant ridge was subducted. Since the thermal time constant of a $10-\mathrm{km}$-thick crustal layer has been estimated as several million years, the thermal effect of the subduction of the Nazca Ridge, which occurred between 7 and $2.5 \mathrm{Ma}$, can still remain.

\section{CONCLUSIONS}

This study demonstrates that estimating heat flow from gas-hydrate BSRs is effective in two-dimensional heat-flow mapping. Temperature measurements in ODP drill holes were also useful, especially in the shallow sea area. It is desirable, however, to develop a new temperature probe to measure drill holes more efficiently.

The general pattern of heat-flow distribution in the central Peru margin is similar to those of other subduction zones. At the bottom of the trench, heat flow is low (lower than 40 $\mathrm{mW} / \mathrm{m}^{2}$ ) and variable. This is partly due to rapid accumulation of trench axis turbidites. Hydrothermal circulation in the Mendaña Fracture Zone and normal faulting on the seaward slope may also play some part. Heat flow on the landward slope is 40 to $50 \mathrm{~mW} / \mathrm{m}^{2}$ and slightly higher than in other subduction zones, except for the Nankai Trough. One possible explanation of this higher heat flow is higher frictional heating along the shear zone between the upper and lower plates. We hope that a heat-flow profile from the coast across the Andes will be obtained to examine whether a high heat flow zone exists in the arc without active volcanism.

\section{ACKNOWLEDGMENTS}

We are grateful for efficient cooperation of the officers, crew, and scientific staff during the MW8506 cruise of the Moana Wave. We thank Donald Hussong and LaVerne Kulm for providing us the opportunity to measure heat flow during the cruise and the Joint Oceanographic Institutions, Inc. for financial support. We acknowl- 
edge Roland von Huene for supplying us with processed seismicreflection data. Jacques Bourgois kindly showed us the heat-flow data obtained during the SEAPERC cruise of the Jean-Charcot. We thank Roland von Huene and anonymous reviewers for critical comments. This study was supported in part by a Grant-in-Aid for Scientific Research (60420013) from the Ministry of Education, Science and Culture, Japan.

\section{REFERENCES}

Blackwell, D. D., Bowen, R. G., Hull, D. A., Riccio, J., and Steele, J. L., 1982. Heat flow, arc volcanism, and subduction in northern Oregon. J. Geophys. Res., 87:8735-8754.

Bourgois, J., Pautot, G., Bandy, W., Boinet, T., Chotin, P., Huchon, P., Mercier de Lepinay, B., Monge, F., Monlau, J., Pelletier, B., Sosson, M., and von Huene, R., 1988. Seabeam and seismic reflection imaging of the tectonic regime of the Andean continental margin off Peru $\left(4^{\circ} \mathrm{S}\right.$ to $\left.10^{\circ} \mathrm{S}\right)$. Earth Planet. Sci. Lett., 87:111-126.

Bullard, E. C., 1954. The flow of heat through the floor of the Atlantic Ocean. Proc. Roy. Soc. (London), Ser. A, 222:408-429.

Cande, S. C., Leslie, R. B., Parra, J. C., and Hobart, M., 1987. Interaction between the Chile Ridge and Chile Trench: geophysical and geothermal evidence. J. Geophys. Res., 92:495-520.

Davis, E. E., Lister, C.R.B., and Sclater, J. G., 1984. Towards determining the thermal state of old ocean lithosphere: heat-flow measurements from the Blake-Bahama outer ridge, northwestern Atlantic. Geophys. J. Roy. Astro. Soc., 78:507-545.

Hamilton, E. L., 1978. Sound velocity-density relations in seafloor sediments and rocks. J. Acoust. Soc. Am., 63:366-377.

Hasebe, K., Fujii, N., and Uyeda, S., 1970. Thermal processes under island arcs. Tectonophysics, 10:335-355.

Henry, S. G., and Pollack, H. N., 1988. Terrestrial heat flow above the Andean subduction zone in Bolivia and Peru. J. Geophys. Res., 93:15153-15162.

Hobart, M. A., Langseth, M. G., and Anderson, R. N., 1985. A geothermal and geophysical survey on the south flank of the Costa Rica Rift: Sites 504 and 505. In Anderson, R. N., Honnorez, J., Becker, K., et al., Init. Repts. DSDP, 83: Washington (U.S. Govt. Printing Office), 379-404.

Horai, K., 1982. Thermal conductivity of sediments and rocks recovered during DSDP Leg 60. In Hussong, D. M., Uyeda, S., et al., Init. Repts. DSDP, 60: Washington (U.S. Govt. Printing Office), 807-834.

Horai, K., and Von Herzen, R. P., 1985. Measurements of heat flow on Leg 86 of the Deep Sea Drilling Project. In Heath, G. R., Burckle, L. H., et al., Init. Repts. DSDP, 86: Washington (U.S. Govt. Printing Office), 759-777.

Kulm, L. D., Suess, E., Thornburg, T. M., Embley, R. W., Hussong, D. M., and Resig, J. M., 1986. Fluid venting processes and their relation to tectonic styles in subduction zones of the eastern Pacific. Int. Kaiko Conf. Subduction Zones, 28-29. (Abstract)

Lachenbruch A. H., and Brewer, M. C., 1959. Dissipation of the temperature effect in drilling a well in Arctic Alaska. U.S. Geol. Surv. Bull., 1083-C:73-109.

Langseth, M. G., and Hobart, M. A., 1984. A marine geothermal study over deformed sediments of the subduction complex off Oregon and Washington. Eos, Trans. Am. Geophys. Un., 65:1089. (Abstract)

Lehner, P., Doust, H., Bakker, G., Allenbach, P., and Gueneau, J., 1983. Active margins, part 5-South American Trench, Profiles P-1304, P-1307, and P-1017. In Bally, A. W. (Ed.), Seismic Expression of Structural Styles-A Picture and Work Atlas: Tulsa (Am. Assoc. Pet. Geol.), Studies in Geology Series 15:3.4.2-92-3.4.2-109.

Lister, C.R.B., 1972. On the thermal balance of a mid-ocean ridge. Geophys. J. Roy. Astr. Soc., 26:515-535.

Nagihara, S., Kinoshita, H., and Yamano, M., 1989. On the high heat flow in the Nankai Trough area-a simulation study on a heat rebound process. Tectonophysics, 161:33-41.

Ocola, L., 1985. Heat flow in the northeastern Peru: Marañon Basin. Proc. South Am. Symp. Cogeodata, Pap. 20. (in Spanish)

Pautot, G., Bourgois, J., Bandy, W., Boinet, T., Chotin, P., Huchon, P., Mercier de Lepinay, B., Monge, F., Monlau, J., Pelletier, B., Sosson, M., and von Huene, R., 1986. Fragmentation of the Nazca Plate west of the Peru Trench: results of the R.V. Jean-Charcot SEAPERC cruise (July 1986). C. R. Acad. Sci. Paris, 303:1651-1656. (in French with English abstract)
Ratcliffe, E. H., 1960. The thermal conductivities of ocean sediments. J. Geophys. Res., 65:1535-1541.

Shipboard Scientific Party, 1988. Introduction, objectives, and principal results, Leg 112, Peru continental margin. In Suess, E., von Huene, R., et al., Proc. ODP, Init. Repts., 112: College Station, TX (Ocean Drilling Program), 5-23.

Suess, E., von Huene, R., et al., 1988. Proc. ODP, Init. Repts., 112: College Station, TX (Ocean Drilling Program).

Toksöz, M. N., Minear, J. W., and Julian, B. R., 1971. Temperature field and geophysical effects of a downgoing slab. J. Geophys. Res., 76:1113-1138.

Uyeda, S., Watanabe, T., Ozasayama, Y., and Ibaragi, K., 1980. Report of heat flow measurements in Peru and Ecuador. Bull. Earthq. Res. Inst. Univ. Tokyo, 55:55-74.

Von Herzen, R. P., 1959. Heat-flow values from the southeastern Pacific. Nature, 183:882-883.

Von Herzen, R., and Maxwell, A. E., 1959. The measurement of thermal conductivity of deep-sea sediments by a needle-probe method. J. Geophys. Res., 64:1557-1563.

Von Herzen, R. P., and Uyeda, S., 1963. Heat flow through the eastern Pacific Ocean floor. J. Geophys. Res., 68:4219-4250.

von Huene, R., Langseth, M., Nasu, N., and Okada, H., 1980. Summary, Japan Trench transect. In Shipboard Scientific Party, Init. Repts. DSDP, 56, 57 (Pt. 1): Washington (U.S. Govt. Printing Office), 473-488.

von Huene, R., Kulm, L. D., and Miller, J., 1985. Structure of the frontal part of the Andean convergent margin. J. Geophys. Res., 90:5429-5442.

von Huene, R., and Miller, J., 1988. Migrated multichannel seismicreflection records across the Peru continental margin. In Suess, E., von Huene, R., et al., Proc. ODP, Init. Repts., 112: College Station, TX (Ocean Drilling Program), 109-124.

Wang, C.-Y., Shi, Y., and von Huene, R., 1987. Thermal structures of two convergent margins-Subduction accretion vs. subduction erosion. Eos, Trans. Am. Geophys. Un., 68:1467. (Abstract)

Warsi, W.E.K., Hilde, T.W.C., and Searle, R. C., 1983. Convergence structures of the Peru Trench between $10^{\circ} \mathrm{S}$ and $14^{\circ} \mathrm{S}$. Tectonophysics, 99:313-329.

Warsi, W.E.K., and Hilde, T.W.C., 1987. Incipient spreading within the Nazca Plate: A consequence of subduction along the Peru Trench. Proc. Pacific Rim Congr., 87:463-468.

Watanabe, T., Langseth, M. G., and Anderson, R. N., 1977. Heat flow in back-arc basins of the western Pacific. In Talwani, M., and Pitman III, W. C. (Eds.), Island Arcs, Deep Sea Trenches, and Back-arc Basins: Washington (Am. Geophys. Un.), Maurice Ewing Ser., Vol. 1, 137-167.

Watanabe, T., Uyeda, S., Guzman Roa, J. A., Cabre, R., and Kubonuma, H., 1980. Report of heat flow measurements in Bolivia. Bull. Earthq. Res. Inst. Univ. Tokyo, 55:43-54.

Woollard, G. P., and Kulm, L. D., 1981. History of Nazca Plate Project. In Kulm, L. D., Dymond, J., Dasch, E. J., and Hussong, D. M. (Eds.), Nazca Plate: Crustal Formation and Andean Convergence. Geol. Soc. Am. Mem., 154:3-24.

Yamano, M., Uyeda, S., Aoki, Y., and Shipley, T. H., 1982. Estimates of heat flow derived from gas hydrates. Geology, 10:339-343.

Yamano, M., Honda, S., and Uyeda, S., 1984. Nankai Trough: A hot trench? Mar. Geophys. Res., 6:187-203.

Yamano, M., Kinoshita, M., and Uyeda, S., 1987. Heat flow distribution in the Japan Trench and the Kuril Trench areas. Program and Abstr. Seismol. Soc. Japan, 1987, No.1:133. (Abstract in Japanese)

Yamano, M., and Uyeda, S., 1988. Heat flow. In Nairn, A.E.M., Stehli, F. G., and Uyeda, S. (Eds.), The Ocean Basins and Margins, Vol. 7B, The Pacific Ocean: New York (Plenum Press), 523-557.

Yokota, T., Kinoshita, H., and Uyeda, S., 1980. New DSDP (Deep Sea Drilling Project) downhole temperature probe utilizing IC RAM (memory) elements. Bull. Earthq. Res. Inst. Univ. Tokyo, 55:75-88.

Ziagos, J. P., Blackwell, D. D., and Mooser, F., 1985. Heat flow in southern Mexico and the thermal effects of subduction. J. Geophys. Res., 90:5410-5420.

Date of initial receipt: 25 October 1988

Date of acceptance: 8 May 1989

Ms 112B-171 